\title{
Modeling the Dynamics of Processes in the Labor Market at the State Level, Applying a Model of Competition with Self-Regulation of Numbers
}

\author{
Nabi Saidkarimovich Ziyadullaev ${ }^{1 *}$, Nikolay Vasilyevich Lyasnikov ${ }^{1-2}$, Evgeniy Danilovich Katulsky ${ }^{3}$, Nataliya Vla- \\ dimirovna Vysotskaya ${ }^{4}$, Olga Anatolievna Pak ${ }^{5}$ \\ ${ }^{1}$ Market Economy Institute of RAS (MEI RAS), Nakhimovsky Av., 47, Moscow, 117418, Russian Federation \\ ${ }^{2}$ Russian Presidential Academy of National Economy and Public Administration (RANEPA) Vernadsky Av., 82, Moscow, 119571, Rus- \\ sian Federation \\ ${ }^{3}$ Research Institute of Labor and Social Insurance, Zemlyanoi Val St., 34, Moscow, 105064, Russian Federation \\ ${ }^{4}$ Moscow Metropolitan Governance University, Sretenka St., 28, Moscow, 107045, Russian Federation \\ ${ }^{5}$ Kuban State University, Stavropolskaya St., 149, Krasnodar, 350042, Russian Federation \\ *Corresponding author E-mail: ziyadullaev.n.s@mail.ru
}

\begin{abstract}
The article reviews possibilities of economic and mathematical modeling in labor market management. A model of the dynamics of processes in the labor market at the state level, applying a model of competition with self-regulation of numbers, is presented.
\end{abstract}

Keywords: Dynamics of numbers; Economic and mathematical modeling; Growth.

\section{Introduction}

Establishment of market relations in Russia has entailed the emergence of various positive and negative phenomena and processes in the field of labor. For example, the labor market has began to shape in the country, the army of the unemployed has emerged, the system of labor motivation and methods of distribution and redistribution of public goods have changed, and other changes have occurred in this and other areas of human life.

Two approaches can be used to eliminate negative phenomena and processes and improve the situation in the labor market. Firstly, the mechanism of the labor market self-regulation can be used for this purpose, and secondly, the state can intervene in the current market situation to improve it [1].

Analysis of the functioning of countries with developed market economies reveals that the mechanism of their self-regulation is insufficient. State intervention in the economy is required. This is especially relevant for economies where the mechanism of selfregulation has not yet fully shaped. The same applies to the labor market operation. This necessitates the research on the state of the national and regional labor markets, areas and intensity of their development, mechanisms for managing them and measures to improve their situation [2].

The efficiency of such research largely depends on methods and tools that scientists use when conducting this research. Each science will only achieve perfection when it uses modern methods of research, including such general scientific methods as modeling, formalization, system approach, etc. [3, 4].

Application of mathematical methods and models is fundamental in the introduction of the method of formalization in modern science - in particular, economics. This also applies to the arrangement of labor market management. The efficiency of this man- agement requires reliable information on the labor market situation and areas of its transformation, the employment situation and the criticality of unemployment, links among the factors describing this market, accurate information about the extent to which the market self-regulatory mechanism and the degree of interdependence of labor macroeconomic factors have been formed, i.e. to what extent the volume terms of the labor market are linked to its financial and cost characteristics, and how flexibly the labor demand and supply respond to the inconsistencies that arise between efficiency and wages. It is quite difficult to accomplish these tasks without using mathematical methods and models. As such, the application of these methods in economic analysis is an urgent task for the development of economics.

The goal of the study is to build a model of the dynamics of processes in the labor market at the state level, applying a model of competition with self-regulation of numbers.

\section{Methodological Aspects of the Economic and Mathematical Modeling of the Labor Market}

The labor market is a complex dynamic system, which is managed through accounting, analysis, planning, forecasting and regulation of this market. The labor market is managed not consistently in accordance with these phases, when one phase follows another, but simultaneously, constantly developing new solutions based on the analysis of the current situation that has developed in the market.

Economists use various models of the labor market combined with the markets for money and products, and under various conditions - in particular, the lack of full employment, etc. The information obtained on the state of the labor market is analyzed. The task of 
this analysis is to identify the situation existing in a particular labor market, how tense it is in comparison with full employment and in comparison, with other labor markets. The results of accounting and analysis of the labor market are used in planning, forecasting and regulation [5]

It is sufficient to have a value of any of the indicators (factors) to assess the state of some systems, but one indicator is insufficient for determining the situation that has developed in the labor market. For example, if there are more unemployed in one region than in another, this does not mean that the labor market is worse in the former region than in the latter. It may have more economically active population or more vacant jobs than in the second region. Therefore, several indicators must be simultaneously used to assess the situation in the labor market of the country (region).

The lexicographic method can be used to solve these problems if there is a considerable difference between the priorities of the indicators used. Priorities of the indicators used can be determined through the expert evaluation. If the indicators differ little from each other in priority, then any method of convolution can be used to build a general (complex, integral) indicator of the state of the labor market. Such indicators are often used for the analysis of economic phenomena and processes. The algorithms for their building are described in full in works [6, 7].

Most often, the generalizing indicators are built in an additive form, although sometimes multiplicative or other models are used to build them. The values of source indicators with different dimensions are usually standardized (normalized) when they are compared, before building such an indicator in order to eliminate the effect of dimensionality. This procedure consists in introducing a single scale for all these indicators or reducing them to dimensionless values. There are many ways to perform this procedure, but the most common of these is the normalization of the partial measures by their average quadratic deviations. However, this method of standardization has its drawbacks - in particular, the fact that dimensionless quantities will have both positive and negative values.

Aside from the reviewed methods and models, other known statistical and econometric methods and models can be used - in particular, methods of correlation, regression, factor, component analysis and other methods, - to study the state and dynamics of the labor market or its components, i.e. demand, supply, cost and price of labor.

Econometric modeling can be applied to study various components of the labor market. In particular, it applies to education, health and other characteristics of human potential, its transformation, employment, structure of vacant jobs, etc. [8].

Some authors suggest using imitation modeling to study the dynamics of the labor market [9]. This approach allows not only constantly monitoring the parameters of the local labor market, but also predicting changes in its state and choosing the most appropriate control measures for the relevant processes.

E. Balatsky made a significant contribution to the development of economic and mathematical models of labor market management This scientist reviews theoretical models of monetary, financial and budgetary regulation of employment in work [10]. The entire economic cycle is analyzed, which starts with state macrodecisions and ends with a growth in the number of the employed. This analysis is based on tracking the chain of "classical" macroeconomic multipliers involved in this cycle. The scientific work of this author [11] is devoted to the study of flexibility (elasticity) of the labor market, i.e. the ability of the labor supply and demand to respond flexibly to discrepancies arising between the equilibrium and actual wages.

Most of the models under review assume that the source information used in them is reliable. However, there are some reasons why it is difficult or even impossible to obtain reliable data on the state of the labor market or the values of other necessary indicators. For this purpose, scientists offer various ways to improve the reliability of the source information. These are the extension of the statistical base for research, the increase in the number and fre- quency of statistical surveys, and the introduction of modern information technology.

\section{Modeling the Dynamics of Processes in the Labor Market, Applying a Model of Com- petition with Self-Regulation of Numbers}

It is advisable to use the model of competition with self-regulation of numbers for analyzing the dynamics of processes in the labor market at the state and industry level.

During the analysis of the development processes in the labor market, it is assumed that

$x_{1}$ is the number of the employed in the country, and

$x_{2}$ is the number of unemployed.

The growth in the number of the employed is due to the expansion of the labor market by attracting young professionals, and is reflected by the coefficient $\xi_{1}$, which is found using the following formula:

$\xi_{1}=\sum \frac{x_{1}^{i}-x_{1}^{0}}{x_{1}^{0}} / n$

where $x_{l}{ }^{i}$ is the number of the employed in the given period, $x_{1}{ }^{0}$ is the number of the employed in the base period, and $n$ is the number of periods.

The desire to have experts of higher qualification predetermines competition in the labor market. At the same time, some part of the economically active population that reach retirement age or for various reasons quit their jobs do not want to work for some time. Due to this, part of the employed described by probability $a_{11}$ lose their jobs.

Assume there is probability $a_{12}$ that an unemployed specialist who was searching for a job has found it, i.e. the number of the employed will increase by $a_{12} x_{2}$.

The dependence revealing the dynamics of the number of the employed in the country, taking into account the probability of search for and loss of job, is described by the following differential equation:

$\frac{d x_{1}}{d t}=x_{1}\left(\xi_{1}-a_{11} x_{1}+a_{12} x_{2}\right.$

Let us assume that the number of the unemployed grows as a result of job cuts with a coefficient $\xi_{2}$, which is found using the following formula:

$\xi_{2}=\sum \frac{x_{2}^{i}-x_{2}^{0}}{x_{2}^{0}} / n$

where $x_{2}{ }^{i}$ is the number of the unemployed in the given period, $x_{2}{ }^{0}$ is the number of the unemployed in the base period, and $n$ is the number of periods.

Let us assume that part of the unemployed specialists that are described by probability $a_{22}$ are those who were looking for a job and found it. Then the total number of the unemployed during period $\Delta \mathrm{t}$ decreased by $a_{22} x_{2}$.

At the same time, the number of the unemployed grows due to young people who have not found a job, pensioners willing to get a job, and people laid off from their previous jobs. These changes are reflected by $a_{21} x_{1}$.

The dependence that describes the dynamics of the number of the unemployed in the country, taking the probability of finding and losing a job into account, can be described by the following differential equation:

$\frac{d x_{2}}{d t}=x_{2}\left(\xi_{2}-a_{21} x_{1}+a_{22} x_{2}\right.$ 
As such, the relationships in the system reflecting the dynamics of the number of the employed and unemployed in the country should be described by the following system of differential equations:

$$
\left\{\begin{array}{l}
\frac{d x_{1}}{d t}=x_{1}\left(\xi_{1}-a_{11} x_{1}+a_{12} x_{2}\right. \\
\frac{d x_{2}}{d t}=x_{2}\left(\xi_{2}-a_{21} x_{1}+a_{22} x_{2}\right.
\end{array}\right.
$$

where $x_{I}^{t i}$ is the number of people employed in the country at the time $t_{\mathrm{i}} \square\left(t_{0} ;+\infty\right)$;

$x_{2}{ }^{t i}$ is the number of the unemployed at the time $t_{\mathrm{i}} \square\left(t_{\mathrm{o}} ;+\infty\right)$; $a_{11}$ is the probability that a working specialist will lose a job; $a_{12}$ is the probability that an unemployed will get a job; $a_{21}$ is the probability that a working specialist will lose a job $\left(a_{11} \neq\right.$ $a_{21}$;

$a_{22}$ is the probability that an unemployed will get a job $\left(a_{12} \neq a_{22}\right)$; $\xi_{1}$ is the coefficient of growth in the number of the employed due to the economy expansion; and

$\xi_{2}$ is the coefficient of growth in the number of the unemployed. The problem can only be solved if the following indicators are available:

- the number of the unemployed in the country at the beginning of the given period $\left(x_{2}^{0}\right)$; and

- the number of the employed in the country at the beginning of the given period $\left(x_{I}^{0}\right)$.

\section{Conclusion}

Economic and mathematical modeling is used at each phase of labor market management. Various methods can be used to assess the state and dynamics of the labor market. At the same time, aside from statistical information, the expert information can also be used as the primary data for performing calculations.

To manage the labor market, scientists use the developed models of labor force reproduction, unemployment regulation and forecasting, and assessing its natural level. Besides, statistical and econometric methods and models - in particular, methods of correlation, regression, factor, component analysis, etc., can be used to study the labor market or its components, i.e. labor demand, supply, cost and price.

The article presents the economic and mathematical model of the dynamics of processes in the labor market at the level of the state and industry, taking the self-regulation of numbers into account. This model can be used to analyze and predict the dynamics of the labor market in the country.

\section{References}

[1] Ermolaeva SG (2015), Rynok truda [Labor market]. Yekaterinburg: Publishing House of Ural University.

[2] Kapelyushnikov R \& Oschepkov A (2014), Rossiyskiy rynok truda: paradoksy postkrizisnogo razvitiya [Russian labor market: paradoxes of post-crisis development]. Issues of Economics 7, 66-92.

[3] Dudin MN, Prokof'ev MN, Fedorova IJ \& Frygin AV (2014), The world experience of transformation of innovative approaches to assurance of financial stability of social economic systems. Life Science Journal 11(9), 370-373.

[4] Dudin MN, Frolova EE, Kucherenko PA, Vernikov VA \& Voykova NA (2016), China in Innovative Development of Alternative Energy Advanced Industrial Technologies. International Journal of Energy Economics and Policy 6(3), 537-541.

[5] Fedoseev VV (2005), Ekonomiko-matematicheskiye modeli prognozirovaniye rynka truda [Economic and mathematical models and labor market forecasting]. Moscow: High School Textbook.

[6] Boeters S \& Savard L (2012), The Labour Market in Computable General Equilibrium Models. In: P.B. Dixon, D. Jorgenson (eds.), Handbook of Computable General Equilibrium Modeling. Netherlands: North Holland, pp. 1645-1711.
[7] Rodionova LB \& Rodionova OE (2007), Metodika integralnoy otsenki napryazhennosti na rynke truda $\mathrm{v}$ regione [Method of integral assessment of tension in the labor market in the region]. $\mathrm{Hu}$ man and Labor 10, 23-25.

[8] Hendry DF (2000), Econometric Modelling. Nuffield College, Oxford University.

[9] Gorelova GV \& Mandel MV (2012), Imitatsionnoye modelirovaniye kak instrument issledovaniya regionalnogo rynka truda [Simulation modeling as a tool for studying the regional labor market]. Bulletin of Adyghe State University: Economics 4 (111), 230-240.

[10] Balatsky EV (1996), Regulirovaniye zanyatosti v svete teorii multiplikatora [Regulation of employment in the context of the multiplier theory]. World Economy and International Relations 4, 53-67.

[11] Balatsky EV (2006), Neravnovesnyye tseny i gibkost ekonomicheskikh rynkov [Nonequilibrium prices and flexibility of economic markets]. Problems of Forecasting 6, 67-82. 